\title{
Asian Crops in North America
}

Jules Janick

AdDitional INDEX wORDs. agronomic crops, food crops, germplasm, horticultural crops

Summary. More than half of the world's food crops have originated in Asia. Throughout the centuries there has been an exchange of crops between Asia and the rest of the world and, as a result, some of the most well known crops in North America, both food crops and ornamental species, are Asian species. The globalization of the world's economy opens up the possibility of new exchanges.

$\mathrm{T}$ The distribution of plant species over the earth is not uniform (Vavilov, 1992). A few favored areas possess large numbers of species and are the likely incubators of most of our present-day crop plants. These centers of diversity were termed centers of origins by N.I. Vavilov, the great Russian biogeographer. Of the seven World Centers chosen by Vavilov for the origin of cultivated species (Fig. 1), three are found in Asia. These include (I) the tropical south Asiatic center (including India and southeastern Asia), (II) the east Asiatic center, and (III) the southwestern Asiatic center. Old World non-Asian centers include (IV) the Mediterranean center and (V), the Abyssinian center. The two New World centers include (VI) the Central American center and (VII) the Andean center. Northern areas of the world such as Siberia, northern Europe, Canada, and the continental United States, undoubtedly as a result of glaciation in the Ice Age, contain relatively few native species considering their large land mass. As a result, these areas have contributed relatively few world crops with the exception of pasture grasses. The most notable crop contribution from the United States includes strawberry (Fragaria Xananassa), blueberry, cranberry (Vaccinium sp.), and sunflower (Helianthus annuus). The continent we call Asia is often lumped with Europe as Eurasia, for there is no clear demarcation in this large land mass. For purposes of this discussion we will consider Asia distinct from Europe. While more than half of the world's important crop species originate in Asia, a transfer of crop species has been underway since Antiquity via the spice and silk routes and was intensified in the Age of Exploration beginning in the $15^{\text {th }}$ century as major crops were exchanged. The ancient history of this transfer is suggested in the many misnomers that occur in our crop names, such as the binomial Prunus persica for peach, suggesting that it came from Persia. It is now clear that Persia was just a byway, as the peach originates in eastern China (Faust and Timon, 1995). 
In a similar way, the early European name for maize (Zea mays), a native of the New World, was turkish corn, and our native bird was named the turkey when its origin was misidentified in Europe. We know of the ancient contacts between eastern Asia and the Middle East from the biblical mention of the spice trade. Many true Asian spices such as cinnamon (Cinnamomum zeylanicum) and cassia (C. cassia) were mentioned in the Hebrew Bible but never grown in the Middle East. This exchange over the years was not one way. A number of New World crops became extremely important in Asia and have become an essential part of their cuisine. The best example is hot peppers (Capsicum annumm and C.frutescens). A number of species such as hevea rubber (Hevea brasiliensis), native to the Amazon area of South America, now have their center of production in Asia. Grain amaranth (Amaranthus sp.), once an important grain of the Aztecs, had virtually disappeared as a crop in the Americas until recently but established itself in India, Pakistan, and China.

The major objective of this paper is to list the important food crops that originated in Asia and that are presently cultivated in North America, with emphasis on the continental United States and Canada. Particular attention will be placed on fruit and vegetables. Much of the information has been gleaned from two recent references: The Evolution of Crop Plants ( $2^{\text {nd }}$ ed.) (Smartt and Simmonds, 1995) and The New Oxford Book of Food Plants (Vaughan and Geissler, 1997).

\section{Grains, sugar crops, and pseudograins}

Rice (Oryza sativa). Rice is the major grain of Asia where it is grown principally as a wetland but also as a dryland crop. In the United States, rice is currently grown chiefly in California and Arkansas.

WheAt (Triticum sp.). The tetraploid Triticum species (AABB) are native to the Near East while the D genome of the hexaploid breadwheats (AABBDD), Triticum aestioum, derives from goatgrass (Aegilops squarrosa), which is Asiatic in origin.

BARLeY (Hordeum vulgare). Barley was domesticated from wild races found today in southwestern Asia. Barley still remains an important grain in the United States and Canada where it is used for animal feed for brewing malts, and, in a minor way, for human food.

Oats (Avena sativa). Oats originated in southwestern Asia and was once an important grain crop in the United States for feed, especially for horses, and was widely used in rotations. Despite its use as a nutritious food for humans, oat production is declining in the United States.

Cane sugar (Saccharum officinalis). Modern sugarcane is principally $S$. officinarum, the thick-stemmed (noble) canes from the South Pacific, and $S$. sinense and $S$. barberi, thinstemmed hardy canes from China and India, respectively. A number of other species, such as $S$. robustrum are wild canes of southeast Asia, have also been important in breeding.

BUCKWHEAt (Fagopyrum esculentum). Buckwheat, native to China, is a minor pseudograin in the United States where its best known use is for buckwheat pancakes. Buckwheat is a common food plant in eastern Europe for cooked groats (kasha) and in Japan where it is the ingredient for soba noodles. The high nutritional value of buckwheat has encouraged consideration in the United States as a nutriceutical.

\section{Pulse crops, grain legumes, and oilseeds}

SoYbean (Glycine max) native to China is grown throughout Asia for a number of uses including miso (soy paste), shoyu (soy sauce), tofu (soy curd), soy milk, and tempeh (a cultured product), while the immature green beans and sprouts are also consumed. The soybean was introduced in the United States as early as the $18^{\text {th }}$ century and first grown as a forage crop. In the $20^{\text {th }}$ century the soybean was transformed in the United States to a protein and oil crop and is now the most important new crop of the $20^{\text {th }}$ century, rivaling maize. Edamame soybean, widely consumed in Japan as a snack food, is a potential new crop for the United States.

Common bean (Phaseolus commu$n i s)$, which is grown as a green or dry bean in the United States is native to the New World, although a number of Phaseolus species are native to Asia including adzuki bean ( $P$. angularis), mungbean ( $P$. areolus), rice bean $(P$. calcaracus), and urdbean (P. mungo). Other vegetables and grain legumes native to Asia include chickpea (Cicer arietinum), favabean (Vicia faba), and lentil (Lens esculenta). None of these crops are grown in any significant way in North America and all are potential new crops. The garden pea (Pisum sativum) was domesticated in southwestern Asia and the eastern Mediterranean and was spread to Europe by the Romans. It spread eastward to India and reached China about 1000 CE.

Sesame (Sesamum indicum), one of the world's most ancient oilseeds, is native to the Indian subcontinent, as indicated correctly by its name. The forage legumes such as alfalfa (Medicago sativa) and persian clover (Trifolium resupinatum) are native to Asia minor.

\section{Vegetables}

Crucifers. Horticultural variants of Brassica oleracea including heading cabbage, broccoli, cauliflower, and brussels sprouts were domesticated in Europe. However, there are many Asian crucifers that include compactheaded chinese cabbage or pe-tsai ( $B$. pekinensis) and other forms with loose rosettes such as wong bok and chibli. A popular Asian crucifer known as pakchoi (B. chinensis) is widely used in Chinese stir fry dishes.

Roor CROPs. Turnip (Brassica campestris) originates in the Middle East and Persia. The origins of radish (Raphanus satious) are obscure, but areas east of the Mediterranean are considered the probable source. Popular Asian root crops include alliums, carrot (Daucuscarota), turnip, and radish. The cultivated alliums [onion ( $A$. cepa), garlic (A. sativum), chives, ( $A$. schoenoprasum), and welsh onion ( $A$. fistulosum)] originated in southwest Asia but were spread to Europe very early by the Romans. According to Vavilov, the primary center of origin of onion and garlic is central Asia. The primary origins of the domesticated carrot are Afghanistan and central Asia. The eastern carrot originated in the HimalayanHindu Kush region (Kashmir-Afghanistan) and the center for diversity for the western carrot is the Anatolian region of Asia Minor (Turkey).

Vegetable fruit. Two popular vegetable fruit-eggplant (Solanum melongena) and cucumber (Cucumis sativa) - originated in Asia. Eggplant, known as aubergine in Europe, is a native of tropical Asia and was first brought into cultivation in India. It is now an important part of Middle East- 
ern cuisine. The cucumber is thought to have originated in the foothills of the Himalayas.

Salad crops and greens. The important salad crops that are of Asian origin include lettuce (Lactuca sativa), originating in Asia Minor, and spinach (Spinacia oleracea), originating in Iran.

\section{Fruit and nuts}

Pome fruit. The major pome fruit-apple, pear, and quince-originated in Western Asia (Asia Minor, the Caucasus, Central Asia, and Western China). Malus sierversii is the major species contributing to the cultivated apple $(M . \times$ domestica $)$ and is native to the Heavenly Mountains (Tien Shan) at the boundary between western China and the former Soviet Union to the edge of the Caspian Sea. Wild trees exist today in Kazakhstan. A number of Asian Malus species such as M. floribunda are grown as ornamental crab apples. The european pear (Pyruscommunis), known for its buttery flesh when ripe and delectable flavors, originated in the Near East. Asian pears (P. pyrifolia, and P. ussuriensis) arose independently in China and Japan and are prized there for their unique crisp texture and sweet flavor. Cultivars of $P$. pyrifolia, known by their Japanese name, nashi, have recently increased in popularity in the United States but still represent a small portion of U.S. pear area.

Stone fruit. The genus Prunus is Asian in origin, although some of the cultivated forms originated in Europe, America, and Asia. The almond ( $P$. $d u l c i s)$ and peach $(P$. persica $)$ are native to Asia and China. Sweet cherry $(P$. avium) and tart cherries (P. cerasus) originated in the Near East. The apri$\cot (P$. armeniaca $)$ is native to Central Asia. Plums are the most genetically diverse species of Prunus and are derived from three continents-Europe, Asia, and North America.

Vine fruit. Vitaceae, the grape family, is made up of 14 genera and more than 100 species, and is widely distributed in the tropics and subtropics in Eurasia and North America. Vitis, the only genus that is edible, has given rise to more than 14,000 cultivars, including at least 28 American species and 20 species native to Asia. The cultivated grape (Vitis vinifera) originated in the New East in Antiquity and first spread around the Mediterranean and then worldwide. It is divided into two subspecies: sylvestris of southern and central Europe, northwestern Africa, western Turkey, and Israel; and caucasia, found in Bessarabia, South Russia, Armenia, Caucasia, Anatolia, Iran, Turkestan, and Kashmir. Ameri- can Vitis species such as V. labrusca gave rise to the slip-skin bunch grapes such as 'Concord', 'Catawba', and 'Delaware'. The French Hybrid wine grapes are hybrids between $V$. vinifera and other American species (Reisch and Pratt, 1996).

Kiwifruit (Actinidia deliciosa and A. chinensis) is the most recent example of a newly domesticated fruit. The fruit was long known in China as miboutao and yangtao but was collected rather than cultivated and, until recently, was called chinese gooseberry. It was introduced in Europe in the end of the $19^{\text {th }}$ century and in North America in the beginning of the $20^{\text {th }}$ century. New Zealand nurserymen, particularly Hayward Wright and Bruno Just, were responsible for developing selections and cultivation methods for this crop (Ferguson and Bollard, 1990). The increase in production and worldwide adoption of this fruit is now legendary. Recently, a yellow-fruited cultivar of $A$. chinesis has been selected and is being sold under the name of Zespri ${ }^{\mathrm{TM}}$ Gold.

Citrus. Citrus is native to southern and eastern Asia, but some relatives are found in Australia and Africa. The well-known citrus fruit, orange (Citrus sinensis), mandarin (C. reticulata), lemon (C. limon), lime

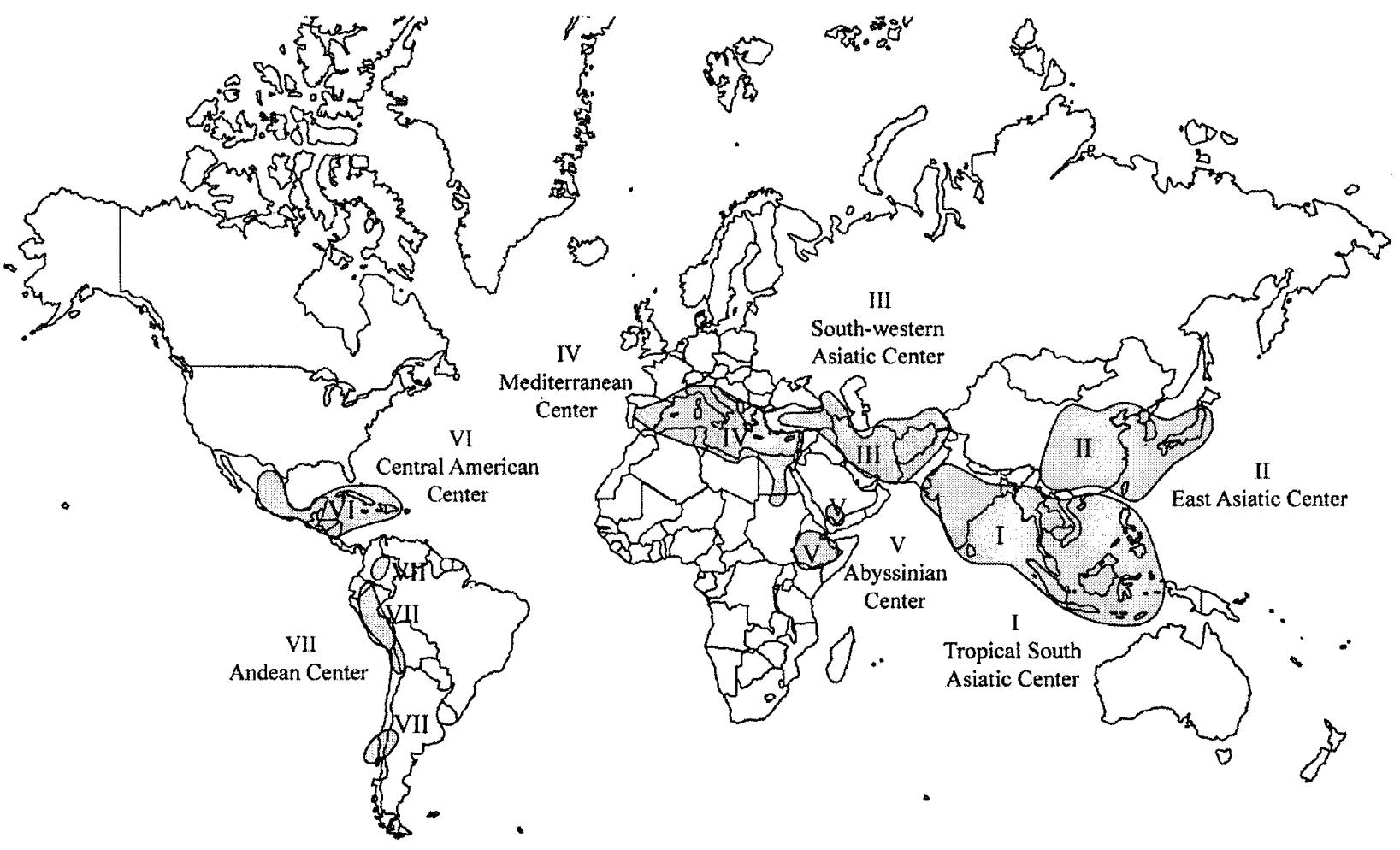

Fig. 1. The Vavilovian centers of origin for crop plants. Adapted from Smith (1995). 
(C. aurantifolia), and their hybrids, are widely grown in the subtropical regions of the United States (Florida, California, Texas, and Arizona), with the exception of the pomelo or shaddock (C. grandis), which requires a tropical climate. The grapefruit, considered by some as a species in its infancy (C. paradisi), originated in the Caribbean from a chance hybrid of $C$. grandis with $C$. sinensis; a single clone further evolved in the United States via mutation. The grapefruit has been used in breeding and has produced new cultivars.

Tropical fruit. A number of well-known tropical fruit cultivated in tropical American are native to Asia. These include banana and plantain (Musa sp.), breadfruit (Artocarpus altilis), jackfruit (Artocarpus heterophyllus), carambola (Averrhoa carambola), lychee (Litchi chinensis), mango (Mangifera indica), mangosteen (Garcinia mangostana), and pomelo (Citrus grandis).

Nuts. Important nuts native to Asia include almond (Prunus dulcis), tung (Aleuritissp.) (once widely grown in the southern U.S. as an oilseed), coconut (Cocos nucifera), pistachio (Pistachia vera), and persian walnut (Juglans sinensis).

\section{Aromatic crops, herbs, and medicinals}

Most of the important Asian spice plants are tropical and are found only in a small way in tropical America, which includes the southern tip of Florida. These include black pepper (Piper nigrum), cinnamon (Cinnamomum zelyanicum), clove (Eugenia caryophyllus), ginger (Zingiber officinale), and nutmeg (Myristica fragrans). Important medicinals and narcotics such as poppy
(Papaversomniferum) and hemp (Cannabis sativa) are illegal crops in the United States, but the latter is widely grown for marijuana production, while low-THC (delta-9-tetrahydrocannabinol) cultivars are being reconsidered as a fiber crop in Canada. Ginseng is an important Asian medicinal. Production in the United States is typically american ginseng (Panax quinquefolium) rather that the asian ginseng $(P$. ginseng).

\section{Ornamentals}

Many of our most popular ornamentals and landscape plants derive from Asia or are enriched by Asian germplasm. It is beyond the scope of this brief treatment to discuss Asian ornamentals except to list some of the common and interesting Asian plants. Asian perennials include species of Alcea (hollyhock), Anemone, Astilbe, Camellia, Chrysanthemum, and Hosta. There are Asiatic species of Lilium, Iris, Paeonia, Rosa, and Tulipa. Landscape ornamentals include japanese maples (Acer sp.), mimosa (Albizia sp.), japanese dogwood (Cornus sp.), asian crabapples (Malus sp.), japanese cherry and plum (Prunus sp.), korean rhododendron (Rhododendron sp.), pagoda tree (Sophora sp.), and viburnum (Viburnum sp.).

\section{Conclusions}

Many of the traditional agronomic and horticultural crops in North America are of Asiatic origin. Because many of our traditional crops originated in Asia, Asian germplasm resources must be considered for future crop improvement. However, despite the reciprocal exchange of many Asian and non-Asian crops that has taken place over the centuries, many crops were not included. This opens up the possibility of new exchanges of crops. These new Asian crops also represent a possible export market for American agriculture.

Recently, the globalization of the economy plus the increase in immigrants has opened up a market for many Asian crops that are not cultivated in the United States. The increased interest in Asian cuisine, particularly Chinese, Korean, Japanese, Thai, and Indian, has increased demand for new foods and new crops. Interest in new foods also has been encouraged by marketing strategies of large retailers. High diversity found in fruit and vegetable sections of supermarkets has become a successful method to attract and retain the loyalty of food purchasers.

\section{Literature cited}

Faust, M. and B. Timon. 1995. Origin and dissemination of peach. Hort. Rev. 17:331379

Ferguson, A.R. and E.G. Bollard. 1990. Domestication of the kiwifruit, p. 165-246. In: I.J. Warrington and G.C. Weston (eds.). Kiwifruits: Science and management. N.Z. Soc. Hort. Sci., Wellington.

Reisch, B.J. and C. Pratt. 1996. Grapes, p. 297-369. In: J. Janick and J.N. Moore (eds.). Fruit breeding. vol. 2. Vine and small fruits. Wiley, New York.

Smartt, J. and N.W. Simmonds. 1995. Evolution of crop plants. $2^{\text {nd }} \mathrm{ed}$. Longman Scientific \& Technical, Essex, U.K.

Smith, B.D. 1995. The emergence of agriculture. W.H. Freeman and Co., New York.

Vaughan, J.G. and C.A. Geissler. 1997. The new Oxford book of food plants. Oxford Univ. Press, Oxford.

Vavilov, N.I. 1992. The origin and geography of cultivated plants. Cambridge Univ. Press, Cambridge, U.K. 